\title{
JURNAL, JILP
}

(Langue and Parole)

Vol. 1 No. 2 ISSN : 2579-5449 E-ISSN : 2581-1819 (media online)

\section{THE INFLUENCE OF THE MARKETING STATEMENTS FOUND IN WOMEN'S COSMETIC PRODUCTS TO THEIR MINDSET IN DETERMINING THE DEFINITION OF BEAUTY}

\author{
Amelia Yuli Astuti ${ }^{1}$, Febi Oktisyafyeni ${ }^{2}$ \\ Fakultas Sastra Universitas Ekasakti
}

\begin{abstract}
This journal discusses about the influence of the marketing statements found in women's cosmetic products to their mindset in determining the definition of beauty. The writer takes the data from the marketing statements that happened in the commercial advertisements of four most used and commonly shown in audio visual media, such as television, which are Pond's, Citra, Shinzui, and Garnier. The Technique of collecting the data of this thesis is the observation technique which then continued by writing down the conversatios that includes the marketing statements of the commercial advertisements into a form of a transcription. The writer uses the speech-act theory by John Langshaw Austin to analyze the influence of the marketing statements which presented through the conversations in the commercial advertisements, the theory of signs by Charles William Morris to analyze the signs that showed up in the commercial advertisements, and the theory of meaning by Charles Kay Ogden and Ivor Amstrong Richards to analyze the meaning of the symbols of signs that showed up in both the conversations and the narration. The result of this study shows that in every part of those products commercial advertisements, the marketing statements always try to influence the women to believe that indeed having white/bright/light skin means beautiful.
\end{abstract}

Keywords: Influence, Marketing Statements, Beauty

\section{INTRODUCTION}

(C) 2018Jurnal JILP

Language is not only the tool for people to communicate to each other, but also the media for a certain group of people to persuade another particular group of people to follow what they believe is the right thing. The terms of language and power are two things that cannot be separated from each other because "language is power" (Fairlough, 1989:9). According to the previous statement, it is indeed a powerful thing for it can absolutely influence us in any possible way. In order to make it as a meaningful words, not just some utterances, it has to be said by a particular speaker to a particular listener with particular purposes. Fairlough said in his book Language and Power that "language is therefore important enough to merit the attention of all"
(1989:14). This is where the so-called hegemony takes part on playing with other people's mindset.

Now a days, there are so many people using this so-called the power of language for their own purposes. The people who are aiming for the political position in a particular region or country are the perfect examples for this. They often use attractive language with the already chosen and scripted words to be said in front of the public or media with promising possibilities to persuade people to elect them. Another example for this case is the producer of the cosmetic products. They also sell their products with only showing the fairness and benefits of it through the 
available mass media, such as newspaper, magazine, and the audio visual media like television or internet media like YouTube and Instagram. These mass media are the most suitable media for the producer to sell and persuade people to buy and use their products, especially the audio visual media. It is possible to happen since they are the most influencing media which has the ability not only to give us the audio of the commercial advertisements but also the visual proof of it.

In these commercial advertisements of cosmetic products case, the producers try to communicate with the consumers through the commercial advertisements. The producers want to persuade the consumers, which are the women, to believe that their products are indeed useful and are able to make the women look beautiful. The commercial advertisements of cosmetic products that the writer aims in this research paper are those of the whitening cosmetic products. These products paired the word "white, bright, and light" alongside with the word "beauty" together side by side that gives us as the viewers of those commercial advertisements the first idea of thinking in our mind that being white or having white/bright/light skin means beautiful.

Based on the explanation above, the writer interested to analyze how far the marketing statements (which are the words "white", "bright", "light", and "beauty") which found in marketing statements of women's cosmetic products' commercial advertisements would be able to influence the mindset of women in determining the definition of beauty. Searle (in Geoffrey Leech's book:1969) Principles of Pragmatics says that "The utterance of such expressions under certain conditions counts as the making of a promise" (1983:24). Based on what Searle (1969) have said before, Leech (1983) concludes that "a sentence uttered by a certain person or a group of people (the speaker) could be interpreted as a motivation of a promise making by the listener". In this commercial advertisements of women's cosmetic products case, the producers give motivation to the viewers to do use their products because it promises the users an interesting result, which is to be a beautiful woman just like models in the advertisements. Leech (1983) makes his conclusion clear by saying that "pragmatics is defined relative to a speaker or user of the language". In this case, the speaker of the language is the producers of the cosmetic products which speak through the conversation occur between the models in the advertisements. In order to help the writer to conduct this study, the writer uses Geoffrey Leech's pragmatic approach (1983), Theory of Speech-act from John Langshaw Austin (1962), The Theory of Signs from Charles William Morris (1938), and The Theory of Meaning from Ogden and Richards (1927).

In collecting the data, the writer uses the observation research. This research is used to find the data by observing the use of language, which in this case is the marketing statement in women's cosmetic products' commercial advertisements. The observing here is not only for oral source, but also written source, such as articles, manuscript, and dictionary. Based on this method, the writer does some video observations of the women's commercial advertisements on which the marketing statement consist of the words "white, bright, light, and beauty" then write in down onto the form of transcription. The data which have been collected are analyzed as follows:

1. The writer as the researcher analyzes and describes the situation of what comes first in the women's mind in which they have watched the cosmetic commercial advertisement and have heard the marketing statement in it.

2. The writer as the researcher describes how the women take and absorb the marketing statement in the cosmetic's commercial advertisement as the information for them.

3. The final step is to figure out the reason of why the women finally buy those cosmetic products then draw some conclusions.

After finishing the data collection, the researcher does the process to analyze the data to increase the understanding of the study. The followinf steps are the process to analyze the data: 
1.Presenting the transription of the dialogue happened in the commercial advertisements which contain the marketing statements

2.Analyzing the data based on the theories that the writer choose to apply on this research.
3.Giving detailed explanation about the influence of those marketing statements to women's mindset in determining the definition of beauty

4.Drawing out the results of the research

\section{RESEARCH METHODS}

In Citra Pearly White UV Body Lotion commercial advertisement, The producer of this product seems to know and realize exactly that most Indonesian women are obsessed with Korean wave which includes the purity of the Korean people's bright and fair skin. This makes the producer includes the Korean secret potion extract in their product to attract these particular women who obsessed to have skin as bright as Korean people. The producer mentioned the word beauty alongside the word white in their marketing statements which undoubtedly makes any woman who listen to this statements would have a first idea in their mind that having bright/white/light skin means that you are beautiful. This also pragmatically implies the purpose of the producers to influence women's mindset that if they want to be considered as beautiful woman, the first thing that they have to do is to have white/bright/light skin just like those Korean people. The marketing statement that happened in the commercial advertisement can be seen as follows:

Known as the secret of the Korean women for their glowing-beauty skin, Korean pearls. Now Citra Pearly White UV lotion takes the glow benefit of the millions Korean micro pearls for you. The skin becomes softer, glowingbrighter. The glow of millions Korean pearls, that is the glow of Citra's beauty. (Citra Pearly White UV Beauty Lotion).

In Shinzui Body Cleanser commercial advertisements the producer seems to also know that some Indonesian women are obsessed with manga (Japanese comics). This obsession makes some Indonesian women have the desire to have the skin like Japanese women. The producer of this product is even braver than the previous producer because this product mentions their ultimate marketing statement, which is "Because white is Shinzui". They basically imply that their product is the best choice to have white/bright/light skin. They even put their product's name as the definition of what is the meaning of having white skin. The producer basically put stressing on their marketing statement which trying to influence women's mindset that their product is the right one to use to get a white/bright/light skin. The marketing statement that happened in this commercial advertisement can be seen as follows:

Japanese natural formula's legacy, herba matsu oil. Now blends with the extract of sakura flower, exist in Shinzui body cleanser. Makes your soft skin as white as snow, like Japanese women. Because white is Shinzui. (Shinzui Body Cleanser).

In Pond's White Beauty Facial Foam commercial advertisement The description of transition of dark-looked skin into white beauty and white-glowing skin is obviously the main marketing statements in this commercial advertisement to influence the women. These statements persuade women to not be afraid that their skin would be darker because this product will protect and give the women a more whiteglowing skin to be beautiful. The marketing statement that happened in this commercial advertisement can be seen as follows:

Just to be outside for 10 minutes could trigger 10 spots problem and the cause of darklooked skin. New ! Our newest formulation Pond's White Beauty with vitamin b3+, for

Jurnal JILP (Langue and Parole) Vol. 1 No. 2 (2018) ISSN : 2579-5449

This work is licensed under a Creative Commons Attribution-NonCommercial 4.0 International License. 
white-glowing looked skin, covered spot. (Pond's White Beauty Facial Foam).

One of the many things that women hate is waiting for the whitening/brightening/lightening products that they use to show them its result. Almost every woman would like a have their cosmetic products give them an instant result of what they think as their really wishes. The producer of Garnier Light Complete White Speed Moisturizer product seems to notice this situation and make a speedy whitening product which undoubtedly will attract women's attention. By presenting one of the most beautiful Indonesian actresses as the model in this commercial advertisement which already has fair skin, the producer wants to give an impression to influence the women that the result of their product will be as close as what the actress gets. The marketing statement that happened in this commercial advertisement can be seen as follows:

New ! Garnier light complete three days program with 100 times vitamin C ! Step !, apply the serum essence. Step 2, apply the SPF cream, works fast in reducing the spots, and acnes spots. Brightens up in three days !). (Garnier's Light Complete White Speed Moisturizer).

In analyzing the speech-act theory in the marketing statements, the writer took five samples of cosmetic products' commercial advertisements to represent this theory's analysis. Those five commercial advertisements are Pond's White Beauty Facial Foam, Pond's White Beauty Facial Moisturizer, Citra Pearly White Moisturizer, Citra White Lotion-Snow Fairy, and Garnier's Light Complete White Speed Moisturizer. In analyzing the speech-act which happened in the commercial advertisements of these products that aiming to influence women in determining the definition of beauty the writer first sort out the dialogue as to which of the parts of the dialogue should be announced as the locutionary act, illocutionary act, and perlocutionary act.

In Pond's White Beauty Facial Foam product, the locutionary act which contain the marketing statement can be seen in this sentence:
Black spot, the danger of the sunlight and today's pollution, makes the black spot comes faster. In this chance, the model was trying to give a hint upon the problem that can be solved by this product. The illocutionary act can be seen in this sentence: Just to be outside for 10 minutes could trigger 10 spots problem and the cause of dark-looked skin. New! Our newest formulation Pond's White Beauty with vitamin b3+, for white-glowing looked skin, covered spot. This sentence was mentioned by the narrator whom explaining about the cause of the dark skin and also give the solution of it which is if the women want to have white-glowing and dark-spot free skin; they should use this particular product. This product put the word White and Beauty alongside each other to give the impression that having white skin is the identification that you are beautiful. So in order for women to be beautiful, they got to have white skin. The perlocutionary act in this commercial advertisement can be seen as follows: 10 difficulties to solve spots problem and the cause of dark-looked skin, no need to be afraid now. In this sentence, there are two key words that can be found interesting, which are dark-looked and afraid. These two words describe the feelings of women if they have dark-looked skin. They would be afraid to do their activities or to go outside. This can also means that they have lack of confidence if they have dark-looked skin.

In Pond's White Beauty Facial Moisturizer product, the locutionary act can be seen as follows: Representing the voice of young women in Indonesian music. Developing the beauty of batik to be the modern fashion trend. Lifting the value of the youth of the nation onto screen. To achieve the goals, there are many challenges that we all have to face. Like the black spot which difficult to solve that deters us to perform with the best face. Now, the question is, what kind of best face that could help them in achieving their goals ? The answer is mentioned by the narrator exactly after the models said that and will be explained in the illocutionary act. The illocutionary act in this commercial advertisement is: Pond's White Beauty, work on to brighten the black spot even for those which have been there for months. For white-glowing looked skin and covered spots. The narrator explains clearly the answer to the models 
problem which is by using the product. The perlocutionary act in this commercial advertisement can be seen in this sentence: Lighten up and be the part of the new face of Indonesia. This makes the women of course think that in order to be acknowledged as their part of the new face of Indonesia, they should use the same product.

In Citra Pearly White Moisturizer Product,the locutionary act can be seen as follows: Citra takes the softness and the beauty light of natural pearls which enriched with mineral to create Citra Pearly White Moisturizer that gives you a face as beautiful as pearls. The narrator clearly tried to promote the product by giving a hint of what are the extracts inside the product that can give women the skin that they want which is being beautiful by having white/light skin. The illocutionary act in this commercial advertisement can be seen as follows: Wait. Wow... Your face is very soft ! And it's glowing ! The key on this statement are the words soft and glowing. This model clearly doing an act by saying something which is trying to give a hint to the women that this respective product will give them not only white/bright/light skin but also soft and glowing skin. The perlocutionary act can be seen as follows: For soft and glowing face as beautiful as pearls, Citra Pearly White Moisturizer. The narrator concluded the conversation occurred between the two models about the right product that the viewers have to use in order to have beautiful, white, soft, and glowing skin. This is clearly an effort to influence the targeted consumers of this product, which are the women, that if they want to have that kind of skin in order to be beautiful, first thing that they have to do is by using this product.

In Citra White Lotion-Snow Fairy product, the locutionary act can be seen as follows: I want to meet the snow fairy, sis. The second model wanted to make her sister's birthday wish come true but when she looked at her skin that quite dark she felt sorry. Here comes the solution of this problem which portrayed later as the illocutionary act. The illocutionary act in this commercial advertisement is: Oh, No...". This phrase was mentioned by the second model in this advertisement when she looked at her dark skin. She then took an act by using this product which makes her skin becoming brighter and as white as snow. The perlocutionary act in this commercial advertisement is : The skin looks brighter with Citra White Lotion. This sentence was mentioned by the narrator of this advertisement in order to convince the viewers that this product could indeed give the result a bright and white as snow fairy.

In Garnier Light Complete White Speed Moisturizer, the locutionary act can be seen as follows: You just finished your treatment, yes? and Yes. To reduce the dull and the black spot. But it takes long time! and Wow! It takes long time! Just brightens it up in three days ! All women want to have a pretty skin in a speed way. They never really want to wait for too long. Even some wish for some instant results. The illocutionary act of this commercial advertisement can be seen as follows: New! Garnier light complete three days program with 100 times vitamin C! Step !, apply the serum essence. Step 2, apply the SPF cream, works fast in reducing the, spots, and acnes spots. Brightens up in three days ! The narrator explained the extracts in this product which really helpful in order to help the model to get rid of her skin problem. These sentences were clearly made and uttered nicely to convince the viewers that this product is the right choice for the women out there who wanted to have brighter skin without have to wait for too long. The perlocutionary act of this commercial advertisement is: Just try !, It's halal !. These two sentences mentioned by the model implies clearly that it is okay for the Moslem to use this cosmetic product.

In analyzing the signs that shown in the commercial advertisements, the writer uses the theory of sign and takes one perfect sample for this analysis, which is the commercial advertisement of the Citra White Lotion-Snow Fairy product. In order to analyze the theory of sign, the marketing statement in this commercial advertisement should be sort out first upon which of this marketing statement is the sign vehicle, designatum, the interpretant, and the interpreter. The sign vehicle of this product's commercial 
advertisement is the act of the models that looked a bit upset because of her dark skin which way too far from the description of the beauty of a snow fairy, the designatum in this commercial advertisement is the product itself, the interpretant is the use of the word snow and fairy in this commercial advertisement which gives the idea that having skin as fair as the snow fairy, which is white/bright, is the way to be beautiful and attractive, and last the interpreter in this commercial advertisement is the women that represented by the model in this commercial advertisement, because most women would have the same thinking and idea as her about snow fairy.

In analyzing the implication meaning in the marketing statements of these cosmetic products' commercial advertisements, the writer uses the theory of meaning and takes some sample for the analysis. In theory of meaning, the writer uses the triangle of meaning to describe the analysis. To represent the example of the analysis of the imply meaning of those marketing statements in the commercial advertisements, the writer takes one sample of commercial advertisement, which is the Pond's White Beauty Facial Foam product.

The example fot this explanation can be seen as follows. In Pond's White Beauty Facial Foam commercial advertisement, This product persuades women to think that being beautiful

\section{CONCLUSIONS}

There are a lot of things that the writer found after analyzing this study. Some things are bluntly answering the questions that popped out in the writer's mind which the writer put in the formulations of the problem. Things that the writer only assumes in the beginning have finally found the answer and the brief explanation. The findings of this research study could reach out into the purpose of why the writer chooses to write about this topic in the first place. The writer concludes the findings of this study in this chapter of this thesis and the writer hopes that these findings could help us in common to get to know more the way women think about what is beauty and also could open women's mindset about what beauty really is. means having white and flawless skin. The model and the narrator in this commercial advertisement were perfectly played their role in making the viewers believe that in order to be a beautiful woman they had to have white skin. It gives a visualization that having dark skin and black spot is not only a big problem for women to become a beautiful woman but also frightened the women to stay under the sun because they are afraid that their skin will become dark and it means you are not beautiful anymore. The triangle of meaning for this will be as follows:

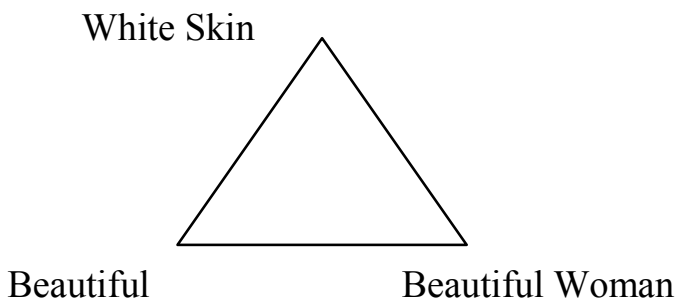

The first thing that the writer found after analyzing this issue is that the producers of these whitening/brightening/lightening cosmetic products really have the knowledge about women's desire of becoming beautiful. They seems to have noticed before that it is easier to reach and approach women through one of their deepest desire which is to look beautiful and it is true. No women in this world who don't want to look beautiful and attractive in front of other people. The producers knew the phenomena in their marketing area so that they make products that includes a piece of thing that connected to the phenomena, for example the use of Korean pearl extract in whitening cosmetic products from brand Citra and the use of Japanese sakura 
flower extract in lightening cosmetic products from brand Shinzui. The producers of these two brands seem to know that Korean wave and Japanese culture are recent trend right now and the women of these two Asian country could be the rightful example of proper white/bright/light skin to be considered as beautiful woman.

The second thing that the writer found after analyzing this issue is that the women really believe that having white/bright/light skin is the way for them to be considered as a beautiful woman. They would feel like they lose their confident and they would have a low self-esteem if they have dark skin. The commercial advertisements showed it clearly through the flawlessly act of the models in it. They showed how women easily get drown in their own thinking that having dark skin makes them less attractive. The attractive marketing statements in the commercial advertisements helped the women in convincing their own thinking that it is true that they have to look flawlessly bright by having white/bright/light skin in order to be considered as a beautiful woman and to be acknowledged by the society around them. The commercial advertisements also showed that having white/bright/light skin is going to help them to achieve their dream no matter what their dream is.

The third thing that the writer found in this study is that the women really influenced by the marketing statement of these cosmetic products. The models in the commercial advertisements should be true about representing women in common. The models are all woman and woman should know about other woman's thinking despite what the producers planned as their marketing strategy. The thing that influenced the women is not only the marketing statements of the cosmetic products which stated perfectly and persuasively by the models and the narrators in the commercial advertisements but also the signs that appeared in it.

The stigma that already exist in the society about having white/bright/skin means you are beautiful, attractive and sometimes you will be considered as someone who comes from high society class makes the women really convinced to buy and use those products in order to be acknowledged. The description of black/dark color as the color of evil, bad, gloom, sad, mourn, and everything that considered as bad luck also successfully make the women convinced about the stigma that having white/bright/light skin means you are beautiful.

There are some things that popped up in the writer's mind after analyzing this study. The writer concludes it in these suggestions below:

1. Women should not be afraid of what they really look. It is okay to not have a bright skin as fair as the models in the commercial advertisements. Every woman is special in their own way. They have their own flaw. Women should accept themselves first to be accepted by others.

2. Trend is not always right and it is not always suit yourself. Be happy with what you already have. Following the trend that the models demonstrated in the commercial advertisements will never make you look exactly like them.

3. Not every woman put the desire to look beautiful as their priority. Some women, including the writer, think that beauty means nothing without brain and attitude. Beauty will fade someday but your intellect and attitude shall remains in you. Beauty might attract people to you but brain and attitude are the two things that would make people impressed on you.

4. The outside beauty that these whitening/brightening/lightening cosmetic products are only an artificial beauty. It might help you to cover your flaw but it will never cover your identity.

5. Women are getting smarter now a days. They should not allow any information and words like the marketing statements in the commercial advertisements to influence their mindset just like that. They have to digest and think over of it. It is time for women to think about their inside priority first before their appearance. It is okay to look decent but to only think about the appearance should not be on the top list. To put it as simple as it is, it is not the appearance that help you in any examination. It is not your beauty that would help you reach your goals and dreams. It is your brain, your intellect, your hard work and your attitude that would help you reach your goals and dreams.

6. Women should respect their own self for whoever they truly are. Never let words change who you really only to be accepted, acknowledged, and to be considered as a beautiful woman. Women should not change their selves only to fit in.

Those are the things that the writer eager to share after analyzing this study. The writer really hopes that women should never really let the

Jurnal JILP (Langue and Parole) Vol. 1 No. 2 (2018) ISSN : 2579-5449

This work is licensed under a Creative Commons Attribution-NonCommercial 4.0 International License. 
words get into their mind easily and ignore who they truly are just to fit in. Be smart and think it over before you decide whether you want to use the products or not. Be wise and think again about the reason of why you want to use the products. It is okay to have the desire to look as beautiful as the models in the commercial advertisements as long as you don't lose your true identity and it changes you into somebody else who you don't even know in your way of it.

\section{SUGGESTION}

Based on the theories that the writer choose to apply on this study, the writer found that the commercial advertisements which chosen by the writer as the data source of the marketing statements were really influencing women's mindset in determining the definition of beauty. As the analysis of the first chosen theory, there are some commercial advertisements which the writer took as the major sample of this research, which are the Citra Pearly White UV Body Lotion, Shinzui Body Cleanser, Pond's White Beauty Facial Foam, and Garnier Light Complete White Speed Moisturizer products. 


\section{Bibliography}

Austin, J. L. 1962. "How to Do Things with Words" in Geoffrey L. (ed.), Principles of Pragmatics. London and New York: Longman.

Djajasudarma, Dr.T.Fatimah. 2006. Metode Linguistik: Ancangan Metode Penelitian dan Kajian. Bandung: PT. Refika Aditama.

Fairlough, Norman. 1989. Language and Power. New York: Longman.

Leech, Geoffrey. 1983. Principles of Pragmatics. London and New York: Longman.

Mey, Jacob L. 1994. Pragmatics: An Introduction. Oxford: Blackwell Publisher, Inc.

Morris, Charles William. 1938. Foundations of the Theory of Signs. Chicago: University of Chicago Press.

McGinty, Sarah Myers. 2001. Power Talk: Using Language to Built Authority and Influence. New York: A Time Warner Company.
Noth, Winfred. 1990. Handbook of Semiotics. Indianapolis: Indiana University Press.

Ogden, C.K. and I.A.Richards. 1927. The Meaning of Meaning. New York: Harcourt, Brace and Company.

Searle, John. 1969. "Speech Acts: An Essay in the Philosophy of Language" in Geoffrey L (ed.), Principles of Pragmatics. London and New York: Longman.

Yule, George. 1996. Pragmatics. Oxford: Oxford University Press

http://www.m.meritnation.com/askanswer/question/what-is-commercialadvertisement/understandingadvertising/1709521 (this site was being accessed on December $9^{\text {th }}, 2016$ at $4: 34$ $\mathrm{pm})$.

http://www.smallbusiness.chron.com/marketingstatement-64369.html (this article was written by Michael Holt. This site was being accessed on December 9 ${ }^{\text {th }}, 2016$ at 4:40 pm) 